\title{
SPANXB1 Gene
}

National Cancer Institute

\section{Source}

National Cancer Institute. SPANXB1 Gene. NCI Thesaurus. Code C92964.

This gene may be involved in spermatid development. 